\section{Tai Chi-trening hos eldre}

Hvert år faller ca. $30 \%$ av eldre personer over 65 år (Cochrane Database Syst Rev 2009; nr. 2: CD007146). En systematisk gjennomgang av 111 randomiserte studier med over 55000 deltakere viste at risiko for fall ble redusert ved trening. Den største risikoreduksjonen fant man ved Tai Chi-

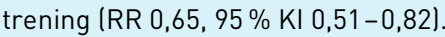

\section{Musikk mot stress og angst?}

Musikkintervensjon har vært forsøkt brukt for å redusere stress og angst hos koronarsyke, som et supplement til tradisjonell medikamentell behandling.

I en systematisk oversikt over 23 randomiserte kontrollerte studier med 1461 deltakere fant man ikke sterke holdepunkter for at musikk reduserte psykiske plager (Cochrane Database Syst Rev 2009; nr. 2: CD006577). Man fant noe redusert blodtrykk samt hjerte- og respirasjonsfrekvens, men funnene var ikke signifikante.

\section{Dødelighet for personer med og uten hiv i Afrika}

Dødeligheten blant hivinfiserte har sunket blant dem med tilgang til antiretroviral terapi i Afrika sør for Sahara. En afrikansk undersøkelse sammenliknet denne dødeligheten med normalbefolkningens i fire ulike afrikanske land (PLoS Med 2009; 6: e1000066).

Blant dem med langtkommet hiv var standardisert mortalitetsratio $47195 \% \mathrm{KI}$ $39-57)$, mens den kun var 3,4 (95\% KI 1,9-6,2) blant dem som fikk antiretroviral behandling i tidlig stadium. Dødeligheten blant hivsyke er mye høyere enn i normalbefolkningen, men ved tidlig intervensjon kan denne reduseres betraktelig.

\section{Marevandosering via automatisk talemaskin}

Marevandosering kan være tidkrevende både for pasienter og helsepersonell. En kanadisk studie unders $ø$ kte effekten av å innføre et maskinelt system for dosering samt automatisk oppringning av pasientene via en talemaskin (CMAJ 2009; 180: 927-33).

1211 av 1557 beskjeder (78 \%) angående dosering ble gitt via talemaskin. Personell måtte gi personlig beskjed 143 ganger ( $9 \%$ av alle beskjeder). 164 av 214 pasienter $(77 \%)$ kunne tenke seg å fortsette med systemet dersom de fikk muligheten.

\title{
Høy smittefare ved svineinfluensa
}

\author{
Svineinfluensa er betydelig mer \\ smittsom enn sesonginfluensa, og \\ smittefaren kan sammenliknes med \\ tidligere influensapandemier.
}

Usikkerhet rundt virulens og smitterisiko til det nye influensaviruset $\mathrm{A}(\mathrm{H} 1 \mathrm{~N} 1)$ (svineinfluensa) har gjort det vanskelig for de ulike lands helsemyndigheter å komme med anbefalinger om tiltak. Nå har forskere i samarbeid med Verdens helseorganisasjon analysert utbruddet i Mexico og tidligere data fra internasjonal spredning (1).

Forskerne estimerte at 23000 personer (spredning 6 000-32 000) innen utgangen av april hadde hatt infeksjonen i Mexico. Basert på bekreftede og mistenkte dødsfall som skyldes $\mathrm{A}(\mathrm{H} 1 \mathrm{~N} 1)$, antydes det at $0,4 \%$ av de syke dør $(0,3-1,5 \%)$. Reproduksjonstallet, som angir hvor mange personer som blir smittet av hver enkelt syk person, ble beregnet til 1,4-1,6 ved epidemiologiske analyser, mot 1,1-1,4 ved vanlig sesonginfluensa.

-23000 tilfeller er nok nærmere realiteten enn de offisielle tallene på mistenkte og bekreftede tilfeller i Mexico, som i dag er 4 174, sier lege Siri Helene Hauge ved
Avdeling for infeksjonsovervåking ved Folkehelseinstituttet. Forskerne tok utgangspunkt i antall laboratoriebekreftede tilfeller hos turister som hadde vært i Mexico, og regnet seg tilbake til hvor mange smittede det må ha vært i Mexico innen utgangen av april. Dette er en lur måte å løse problemet med mangelfulle overvåkingsdata fra Mexico siden turister som vendte tilbake fra Mexico ble fulgt nøye med tanke på influensasymptomer.

- Den største svakheten ved studien er at den bare har inkludert dødelighetsdata fra ett land. Sannsynligvis var antall dødsfall som ble oppgitt i begynnelsen av utbruddet overestimert, og tallene fra USA er nok mer pålitelige. Etter hvert som vi får mer data, vil vi også få et bedre estimat på angrepsrate i befolkningen, hospitalisering og dødelighet, sier Hauge.

\section{Trine B. Haugen}

trine.b.haugen@hf.hio.no

Tidsskriftet

\section{Litteratur \\ Fraser C. Donnelly CA, Cauchemez S et al. Pande- mic potential of a strain of influenza A (H1N1): early findings. Science 2009; 324: 1557-61.}

\section{Steroider etter RSV-infeksjon?}

Høydose inhalasjonssteroider i tre måneder til tidligere friske barn med akutt RSV-bronkiolitt i første leveår hadde ikke forebyggende effekt på residiverende bronkial obstruksjon.

Mange barn har i opptil flere år etter en respiratorisk syncytialt virus (RSV)-bronkiolitt gjentatte episoder med pustebesvær, hoste eller andre symptomer fra nedre luftveier. Nå har nederlandske forskere i en randomisert dobbeltblindet studie undersøkt om residiverende bronkial obstruksjon kan forhindres med terapeutisk intervensjon (1).

243 barn under 13 måneder som ble innlagt på sykehus med RSV-infeksjon, ble randomisert $\mathrm{i}$ to grupper, hvorav den ene fikk $200 \mu \mathrm{g}$ beklometasondipropionat to ganger daglig i tre måneder, mens den andre fikk placebo. Det ble ikke observert signifikante forskjeller i antall dager med bronkial obstruksjon i det påfølgende året $\mathrm{i}$ de to gruppene. Andelen barn med bronkial obstruksjon var heller ikke forskjellig $i$ de to gruppene ( $61 \%$ versus $62 \%$ ).

- Behandling av spedbarn og småbarn med residiverende astmaliknende symptomer er en utfordring, sier seksjonsoverlege Karin C. Lødrup Carlsen ved Barneklinikken, Oslo universitetssykehus, Ullevål. På gruppenivå er det ikke holdepunkter for at steroidbehandling kan begrense den ugunstige immunologiske responsen i etterkant av en RSV-infeksjon.

- Det er ikke dermed slik at denne type behandling ikke virker i det hele tatt, for en del barn responderer godt på inhalasjonssteroider. Den store utfordringen er å identifisere de barna som debuterer med en tidlig astma som vil ha effekt av behandlingen, monitorere behandlingen etter sykdomsaktivitet og avslutte eller skifte behandling der den ikke har effekt, sier Carlsen.

\section{Trine B. Haugen \\ trine.b.haugen@hf.hio.no \\ Tidsskriftet}

Litteratur

Ermers MJ, Rovers MM, van Woensel JB et al. The effect of high dose inhaled corticosteroids on wheeze in infants after respiratory syncytial virus infection: randomised double blind placebo controlled trial. BMJ 2009; 338: b897. 